\section{Ciba Foundation}

\section{COLLOQUIA ON ENDOCRINOLOGY}

\section{Volume II-Hormones in Blood}

Edited by G. E. W. Wolstenholme, O.B.E., M.A., M.B., B.Ch., and Elaine C. P. Millar, A.H.W.C., A.R.I.C. Pp. xii $+4 \mathrm{I} 6$, illustrated. London: J. \& A. Churchill Ltd. r957. 56s.

Continuing its splendid series of Colloquia on Endocrinology, the Ciba Foundation produces this, its eleventh volume. It is devoted almost entirely to problems of identification, isolation and estimation of hormones in the blood. For those to whom this aspect of biology is of special interest, this book will clearly be an important source of invaluable information.

\section{SIDELIGHTS ON THE HISTORY OF MEDICINE}

Edited by Sir Zachary Cope. Pp. $x+246$, with I6 illustrations. London: Butterworth \& Co. Ltd. 1957. 45 s.

This is a selection of papers which have been presented to the Section of History of Medicine of the Royal Society of Medicine over the last 40 years. Sir Zachary has chosen well and wisely kept editing to a minimum. This is a very good form of medical history and the variety of styles makes for easy reading. It is a volume of interest to all ages and branches of the profession and should surely be a part of every undergraduate prize award.
THE PRACTICE OF INDUSTRIAL MEDICINE By T. A. Lloyd-Davies, M.D.F.R.C.P. Second edition. Pp. vii +282 , with 15 diagrams. London: J. \& A. Churchill Ltd. I957. 30 s.

Like the first edition, this book mainly sets out to introduce the subject of industrial medicine to students and to doctors undertaking this kind of work for the first time. The author deals at length with the attitude which must be taken up by a doctor employed by a business concern, but having to gain the confidence of both employers and employees. The special hazards of various occupations and the law relating to them are fairly briefly described, including a short section on the dangers of radioactivity; but the book is not meant as a comprehensive work of reference.

M.N.

\section{FLUID BALANCE IN SURGICAL PRACTICE}

By L. P. Le QUesNe, D.M., F.R.C.S. 2nd edition. $\mathrm{Pp}$. vii $+\mathrm{r} 40$, with 38 illustrations. London: Lloyd-Luke Ltd. I 957. 20 s.

This little book is now in its second edition. The first edition was favourably received and in its present revised form it should be even more popular both with students and with practising surgeons. The text has been largely revised and has been brought up to date, so that this can be considered a thoroughly contemporary account of a rather complex subject. In addition there is a short section, contributed by Dr. B. W. Webb, on fluid balance in children.

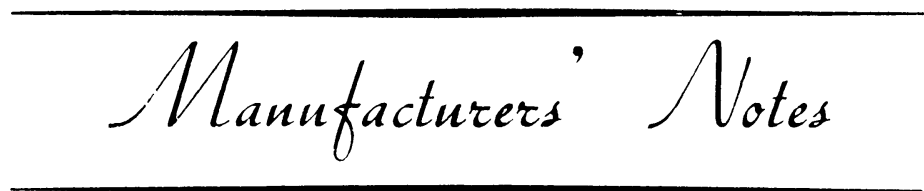

The Distillers Company (Biochemicals) Limited announces the availability of 'Distaquaine' VK tablets, a chemically improved form of 'Distaquaine' V. Each Distaquaine V-K scored tablet contains the equivalent of $125 \mathrm{mg}$. penicillin $\mathrm{V}$ acid (as potassium salt). Potassium penicillin $\mathrm{V}$ is more soluble and therefore absorbed more quickly than penicillin $\mathrm{V}$ acid, resulting in the earlier attainment of peak levels in the blood and in higher therapeutic concentrations.

\section{MOTORIZED VERSION OF PHILIPS D.X.5}

Considerable saving of porters' time can be achieved, it is claimed, with a new, motorized, ward X-ray unit produced by Philips Electrical Ltd. Known as the Motorized D.X.5, it is a modification of the well-known D.X.5 equipment and is expected to become available in April, $195^{8}$.

As well as the established features of rotating anode tube, pre-indicated $\mathrm{m} / \mathrm{A}$ seconds meter and other modern refinements, this new version incorporates a traction unit powered by a $12-\mathrm{v} .57$ amp. acid battery. It has two forward speeds, the lower one having been selected as the most suitable for ' inching' adjustment. The differential drive is arranged as ' power assistance' and the complete unit can negotiate gradients of $I$ in 10 without effort. Reverse control, hub brakes and shock absorbers are also provided. A full battery charge gives approximately four hours of con- 